\title{
Tide assessment for the continental shelf situated in the southwestern Atlantic between the latitudes $19.8^{\circ} \mathrm{S}$ and $21.2^{\circ} \mathrm{S}$
}

\author{
Julio Tomás Aquije Chacaltana ${ }^{*}$, Leonardo Carvalho de Jesus ${ }^{I}$, Fernando Túlio Camilo Barreto $^{I}$, \\ Valdir Innocentini ${ }^{2}$
}

\author{
${ }^{1}$ Universidade Federal do Espírito Santo, Laboratório de Simulação de Escoamentos com Superfície Livre \\ (Av. Fernando Ferrari, 514, Goiabeiras, Vitória, Espírito Santo, Brazil) \\ ${ }^{2}$ Instituto Nacional de Pesquisas Espaciais, Divisão de Meteorologia \\ (Av. dos astronautas, 1758, Jd. Granja, São José dos Campos, São Paulo, Brazil)
}

*Corresponding author: julio.chacaltana@ufes.br

\section{Abstract}

The astronomical tide was numerically simulated by the MOHID model for the South-Central Region of Espírito Santo State (Brazil), between latitudes $19.8^{\circ} \mathrm{S}$ and $21.2^{\circ} \mathrm{S}$. The grid nesting technique was used to transpose the boundary conditions from the larger domain to a more refined local domain (spatial resolution around $450 \mathrm{~m}$ ), with tidal harmonics provided by the TPXO tide inverse model as boundary conditions for the larger domain. Results from the numerical model were compared with both the pre-existing tide harmonics and the harmonics calculated from measured data. From the maps of phase, amplitude, tidal ellipses and residual currents the main tidal kinematic characteristics in the study area were described. On the continental shelf, the results showed that the physiography and bathymetry of the region play an important role in the distribution of tidal co-phases, co-amplitudes, ellipses and residual currents. The MOHID model was able to reproduce satisfactorily the astronomical tide and thus can be used to study the behaviour of the tidal propagation in continental shelf areas.

Descriptors: Astronomical tide, Espírito Santo State, MOHID, Continental shelf, Tide harmonics.

\section{Resumo}

A maré astronômica foi simulada numericamente pelo modelo MOHID para a região Centro-Sul do Estado do Espírito Santo (Brasil), entre as latitudes $19.8^{\circ} \mathrm{S}$ e $21.2^{\circ} \mathrm{S}$. A técnica de aninhamento de grades foi utilizada para transpor as condições de contorno do maior domínio para um domínio local mais refinado (resolução espacial de cerca de $450 \mathrm{~m}$ ), sendo as componentes harmônicas disponibilizadas pelo modelo TPXO utilizadas como condições de contorno para o domínio maior (resolução espacial de cerca de 11,25 km). Os resultados do modelo numérico foram comparados com componentes de maré pré-existentes e com harmônicos calculados a partir de dados medidos. Mapas de fase, amplitude, elipses de maré e correntes residuais foram utilizados para descrever as principais características cinemáticas da maré na área de estudo. Os resultados mostram que a fisiografia e a batimetria da região desempenham um importante papel na distribuição da fase, amplitude, elipses e correntes residuais da maré. O modelo foi capaz de reproduzir satisfatoriamente a maré astronômica, podendo ser utilizado para descrever esse processo em plataforma continental.

Descritores: Maré astronômica, Estado do Espírito Santo, MOHIID, Plataforma continental, Harmônicos de maré. 


\section{INTRODUCTION}

This study was conducted on the continental shelf and slope of the Espírito Santo State (Brazil) between the $19.8^{\circ} \mathrm{S}$ and $21.2^{\circ} \mathrm{S}$ parallels and between the $39.5^{\circ} \mathrm{W}$ and $41^{\circ} \mathrm{W}$ meridians (Figure 1). This region encompasses large fields of oil exploitation and production located in the Campos and Espírito Santo Basins. In addition, in this continental shelf area is located one of the largest port complexes in Brazil (including the Ports of Vitória, Tubarão and Ubu), responsible for the shipping of a large portion of Brazilian minerals and cellulose. Other important activities of this region include artisanal fishing, tourism and navigation.

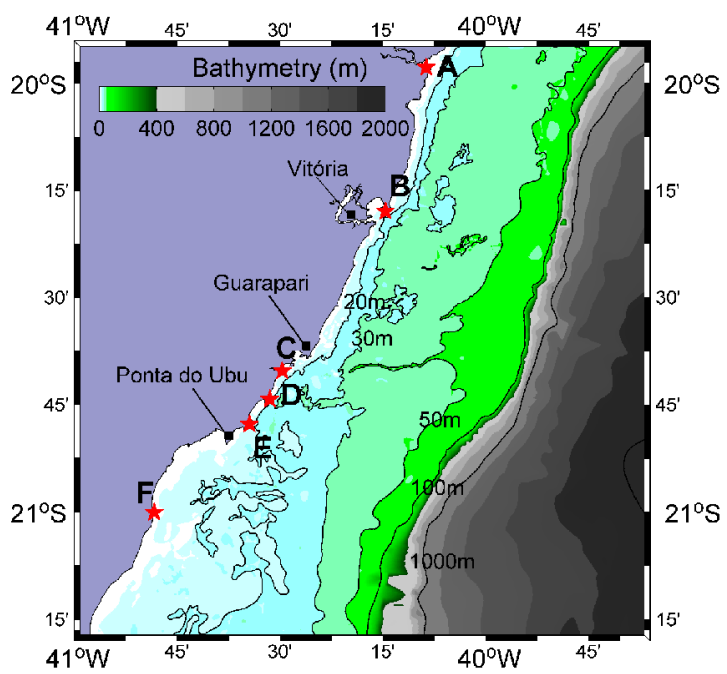

Figure 1. Bathymetry of the study region obtained from digitized and interpolated of depths on nautical charts provided by the Brazilian Navy. The red stars show the location of the tide stations at the coast: A: PiraquêAçú, B: Port of Tubarão, C: Guarapari, D: Meaípe, E: Port of Ubu (Ponta do Ubu) and F - Barra do Itapemirim.

The continental shelf of this region varies in width from $40 \mathrm{~km}$ to $70 \mathrm{~km}$, with the narrowest width to the north and the greatest to the south of the study area. The physical oceanographic environment of the Espírito Santo continental shelf is controlled by the Brazil current and wind regime (SILVEIRA et al., 2000). Studies of the circulation on the continental shelf have been undertaken by several authors, e.g. the circulation generated by winds (STECH; LORENZZETTI, 1992) and the largescale circulation (SCHMIDT et al.,1995; FERNANDES et al., 2009). In the field of operational oceanography for oceanic prediction, we have the study conducted by MARTA-ALMEIDA et al. (2011).
Knowledge of the astronomical tide-induced circulation is the first step to understanding coastal circulation in bays, estuaries and also in the continental shelf area. In Brazil, some studies on tide propagation have been conducted focusing mainly on the continental shelf and coastal circulation of São Paulo state, as in HARARI and CAMARGO (1994, 1998, 2003), MESQUITA and HARARI (2003), CAMARGO and HARARI (2003); however, this kind of study has not yet been undertaken for the Espírito Santo state continental shelf.

Knowledge of the physical-oceanographic characteristics of a specific region can be used to support decision-making and make the definition of strategies possible in the event of environmental hazards and/or for coastal planning. Therefore, the objective of this study is to analyse the kinematic characteristics of the circulation induced by the astronomical tide over the south-central continental shelf of Espírito Santo state.

In this study, the astronomical tide was simulated by the hydrodynamic model MOdelo HIDrodinâmico (MOHID) on a high spatial resolution grid $(450 \mathrm{~m})$, based on the nesting scheme. The phases and amplitudes generated by the TPXO tide inverse model (EGBERT; EROFEEVA, 2002) were imposed on the open boundaries of the largest domain and this information is transferred to the local domain through the one way nesting technique. For the local domain, the numerical results were compared to the tide harmonics provided by the Fundação de Estudos do Mar (FEMAR) for tide stations located in the study area (Table 1) and with the harmonics generated from the surface elevation time series measured at Ponta do Ubu.

Table 1. Specification of the tide gauge stations located in the study area provided by FEMAR (SALLES et al., 2000).

\begin{tabular}{lcc}
\hline Tidal Gauge (number of components) & Latitude & Longitude \\
\hline Piraquê-Açú (36) & $19^{\circ} 57.3^{\prime} \mathrm{S}$ & $40^{\circ} 09.0^{\prime} \mathrm{W}$ \\
Tubarão (36) & $20^{\circ} 17.1^{\prime} \mathrm{S}$ & $40^{\circ} 14.5^{\prime} \mathrm{W}$ \\
Guarapari (35) & $20^{\circ} 40.0^{\prime} \mathrm{S}$ & $40^{\circ} 29.9^{\prime} \mathrm{W}$ \\
Meaípe (36) & $20^{\circ} 44.7^{\prime} \mathrm{S}$ & $40^{\circ} 32.2^{\prime} \mathrm{W}$ \\
Ponta do Ubu (18) & $20^{\circ} 47.1^{\prime} \mathrm{S}$ & $40^{\circ} 34.1^{\prime} \mathrm{W}$ \\
Barra do Itapemirim (35) & $21^{\circ} 00.4^{\prime} \mathrm{S}$ & $40^{\circ} 48.5^{\prime} \mathrm{W}$ \\
\hline
\end{tabular}

The analysis of the numerical results allows us to infer the kinematic characteristics of the tide - such as phase, amplitude, ellipses and energy - in the study region, as well as the role of the continental shelf in the generation of residual currents, the polarisation of tidal ellipses, and energy distribution. 


\section{MATERIAL AND METHODS}

\section{The Physical and Mathematical Model}

To resolve the phase, elevation and velocities induced by the astronomical tide, the vertically integrated equations of mass conservation and momentum were solved numerically, under the Boussinesq and hydrostatic pressure approximations, with the stress due to bottom friction parameterised according to the Quadratic Law of velocity.

The finite volume numerical method is used to solve the momentum and mass conservation equations, with the TVD (Total Variation Diminishing) method being used to solve the advective term on an Arakawa-C type (ARAKAWA, 1997) staggered numerical grid. As proposed by LEENDERTSE (1967), the ADI (Alternate Direction Implicit) method is used for time integration, with the velocity components calculated in time steps centred on time $t+\Delta t / 2$, leading to a second-order precision scheme (MARTINS et al., 2001; MATEUS et al., 2012).

The Flather radiation condition (FLATHER, 1976) was used to irradiate the barotropic velocities; and a bi-harmonic filter, described by DELHEZ and DELEERSNIJDER (2007), was used to remove spurious oscillations caused by the bi-harmonic mixture. This filter basically adds an extra term to the horizontal turbulence flow term to filter high-frequency oscillations related to the advection-diffusion of any property in the numerical model.

The physical and mathematical model is implemented in the MOHID numerical model; further details about the model can be found in SANTOS et al. (2002); MARTINS et al. (1998), VAZ et al. (2009). This hydrodynamic model has been applied in several studies and on different spatial scales, from small scales such as those of estuarine regions and coastal lakes, (MARTINS et al., 2001; MONTERO et al., 1999; VAZ et al., 2005; MALHADAS et al., 2009; VAZ et al., 2009), to larger scales such as those of platforms and basins (SANTOS et al., 2002; LEITÃO et al., 2005; RIFLET et al., 2010).

\section{MODEL CONFIGURATION}

The grid nesting technique was used to transpose the information given on the open boundary of the larger model to the local domain of higher spatial resolution. In this study, three nested grids are used. Details of the grids are shown in Table 2; where L1, L2 and L3 represent the numerical grids, and $\mathrm{Nx}$ and $\mathrm{Ny}$ the number of points in the $\mathrm{X}$ direction (longitude) and in the $\mathrm{Y}$ direction (latitude), respectively.

Table 2. Technical specifications of the three grids used to transpose the global boundary condition to the grid of the study area with the highest spatial resolution.

\begin{tabular}{lcccc}
\hline Grid & Resolution & Origin (lon, lat) & $\mathrm{Nx}$ & $\mathrm{Ny}$ \\
\hline L1 & $0.1^{\circ}$ & $-41.00,-21.56$ & 62 & 37 \\
L2 & $0.02^{\circ}$ & $-40.98,-21.36$ & 93 & 77 \\
L3 & $0.004^{\circ}$ & $-40.966,-21.283$ & 430 & 348 \\
\hline
\end{tabular}

The bathymetry used in this study was obtained from the GEBCO database for the L1 and L2 grids and, to better represent the bathymetry of the continental shelf, the digitised and interpolated values of depth from the nautical charts provided by the Brazilian Navy were used for the L3 grid. The bathymetry corresponding to the study area (L3) is shown in Figure 1.

The phases and amplitudes of the M2, S2, K1, K2, N2, 2N2, O1, Q1, P1, M4, MN4 and MS4 harmonics provided by the TPXO tide inverse model were imposed on the boundaries of the most external grid (L1); the numerical solution of the L1 grid being transposed to the other nested grids through a scheme based on the one-way nesting method (the positions of the nested grids are shown in Figure 2). The velocities and elevations were set to zero for model initialisation (cold start) and the elevation was gradually imposed on the model for the first simulation day.

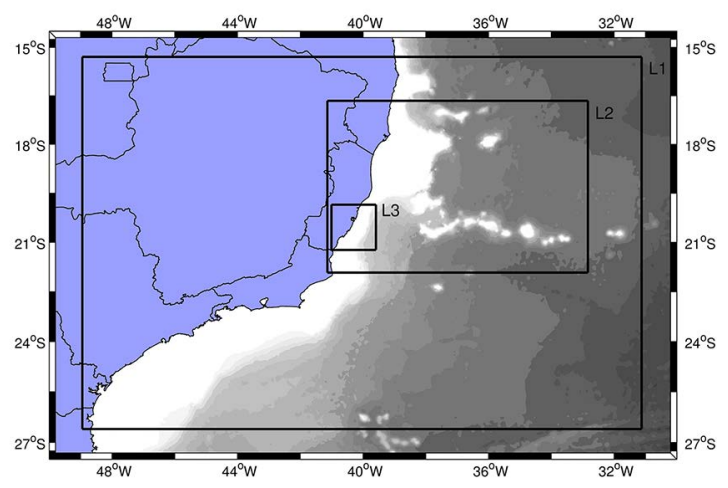

Figure 2. Geographic positions of the grids used to transpose the boundary conditions from the larger grid to the grid with the highest spatial resolution.

The hydrodynamic model ran with the above configurations for a simulation period of two months (June 1st to August 1st, 2008). The numerical results were compared with data from the tide gauge stations located in the study area provided by 
FEMAR (Fundação de Estudos do Mar) (SALLES et al., 2000) and with the time series of water level measured at the Port of Ubu for the same simulated period.

\section{RESULTS}

The elevation time series generated by the numerical model corresponding to the tide gauge stations provided by FEMAR (SALLES et al., 2000) were analysed using the Tide Harmonic Analysis Method (FRANCO, 1988).

In this case, the time domain is represented by the ocean surface elevation records, and the frequency domain is represented by the phases and amplitudes of the tide harmonics (corresponding to the fundamental harmonics of the Fourier series), with nodal corrections and interpolations of phase and amplitude applied to the exact tide frequencies (FRANCO, 1988; FRANCO; HARARI, 1987; HARARI; CAMARGO, 2003). The comparison between the tide harmonics extracted from the numerical results and the harmonics provided by FEMAR for the seven principal harmonics in the study region are shown in Table 3.

The harmonic analysis method was applied to the time series of water elevation (level) measured at the Port of Ubu (Ponta de Ubu - SAMARCO, a Brazilian mining company). Then, with these harmonics and those provided by FEMAR (SALLES et al., 2000), the tide prediction method was used to hindcast the water elevation (level) generated by the astronomical tide alone for this tide station. The results from the harmonic prediction method and the numerical model are shown in Figure 3.

Table 3. Amplitudes and phases calculated for the time series generated by the numerical model and by the analyses of sea level (SALLES et al., 2000).

\begin{tabular}{|c|c|c|c|c|c|c|c|c|c|c|c|c|}
\hline & \multicolumn{2}{|c|}{ Piraquê-Açú } & \multicolumn{2}{|c|}{ Gauge 01} & \multicolumn{2}{|c|}{ Error } & \multicolumn{2}{|c|}{ Tubarão } & \multicolumn{2}{|c|}{ Gauge 02} & \multicolumn{2}{|c|}{ Error } \\
\hline & $\begin{array}{l}\text { Amp. } \\
(\mathrm{cm})\end{array}$ & $\begin{array}{c}\text { Phase } \\
\left({ }^{\circ}\right)\end{array}$ & $\begin{array}{l}\text { Amp. } \\
(\mathrm{cm})\end{array}$ & $\begin{array}{c}\text { Phase } \\
\left({ }^{\circ}\right)\end{array}$ & $\begin{array}{c}\text { Amp. } \\
(\mathrm{cm})\end{array}$ & $\begin{array}{c}\text { Phase } \\
\left({ }^{\circ}\right)\end{array}$ & $\begin{array}{c}\text { Amp. } \\
(\mathrm{cm})\end{array}$ & $\begin{array}{c}\text { Phase } \\
\left(\left(^{\circ}\right)\right.\end{array}$ & $\begin{array}{l}\text { Amp } \\
(\mathrm{cm})\end{array}$ & $\begin{array}{c}\text { Phase } \\
\left({ }^{\circ}\right)\end{array}$ & $\begin{array}{l}\text { Amp. } \\
(\mathrm{cm})\end{array}$ & $\begin{array}{c}\text { Phase } \\
\left({ }^{\circ}\right)\end{array}$ \\
\hline M2 & 44.8 & 84 & 46.49 & 88.5 & 1.69 & 4.5 & 44.2 & 88 & 45.89 & 88.26 & 1.69 & 0.26 \\
\hline $\mathrm{S} 2$ & 21.3 & 94 & 20.58 & 99.47 & -0.72 & 5.47 & 21.9 & 92 & 20.41 & 99.15 & -1.49 & 7.15 \\
\hline $\mathrm{O} 1$ & 8.2 & 81 & 8.76 & 102.01 & 0.56 & 21.01 & 9.1 & 93 & 8.8 & 101.44 & -0.3 & 8.44 \\
\hline K1 & 2 & 188 & 5.74 & 166.43 & 3.74 & -21.5 & 5.5 & 159 & 5.74 & 165.41 & 0.24 & 6.41 \\
\hline Q1 & 2.1 & 62 & 2.33 & 76.4 & 0.23 & 14.4 & 3.1 & 56 & 2.35 & 75.94 & -0.75 & 19.94 \\
\hline $\mathrm{K} 2$ & 5.8 & 94 & 6.08 & 93.3 & 0.28 & -0.7 & 5.9 & 92 & 6.03 & 93.17 & 0.13 & 1.17 \\
\hline \multirow[t]{3}{*}{ N2 } & 3.6 & 76 & 7.2 & 95.91 & 3.6 & 19.91 & 9.8 & 69 & 7.07 & 95.95 & -2.73 & 26.95 \\
\hline & \multicolumn{2}{|c|}{ Guarapari } & \multicolumn{2}{|c|}{ Gauge 03} & \multicolumn{2}{|c|}{ Error } & \multicolumn{2}{|c|}{ Meaípe } & \multicolumn{2}{|c|}{ Gauge 04} & \multicolumn{2}{|c|}{ Error } \\
\hline & $\begin{array}{l}\text { Amp. } \\
(\mathrm{cm})\end{array}$ & $\begin{array}{c}\text { Phase } \\
\left({ }^{\circ}\right)\end{array}$ & $\begin{array}{l}\text { Amp. } \\
(\mathrm{cm})\end{array}$ & $\begin{array}{c}\text { Phase } \\
\left({ }^{\circ}\right)\end{array}$ & $\begin{array}{l}\text { Amp. } \\
(\mathrm{cm})\end{array}$ & $\begin{array}{c}\text { Phase } \\
\left({ }^{\circ}\right)\end{array}$ & $\begin{array}{l}\text { Amp. } \\
(\mathrm{cm})\end{array}$ & $\begin{array}{c}\text { Phase } \\
\left({ }^{\circ}\right)\end{array}$ & $\begin{array}{l}\text { Amp } \\
(\mathrm{cm})\end{array}$ & $\begin{array}{c}\text { Phase } \\
\left({ }^{\circ}\right)\end{array}$ & $\begin{array}{l}\text { Amp } \\
(\mathrm{cm})\end{array}$ & $\begin{array}{c}\text { Phase } \\
\left({ }^{\circ}\right)\end{array}$ \\
\hline M2 & 44.2 & 114 & 46.05 & 88.42 & 1.85 & -25.58 & 45.5 & 85 & 46.38 & 88.52 & 0.88 & 3.52 \\
\hline $\mathrm{S} 2$ & 17.8 & 98 & 20.64 & 99.3 & 2.84 & 1.3 & 18.8 & 90 & 20.8 & 99.46 & 2 & 9.46 \\
\hline O1 & 8.3 & 124 & 8.86 & 101.12 & 0.56 & -22.88 & 10.9 & 88 & 8.88 & 101.14 & -2.02 & 13.14 \\
\hline K1 & 5.3 & 159 & 5.76 & 164.64 & 0.46 & 5.64 & 3.9 & 168 & 5.77 & 164.74 & 1.87 & -3.26 \\
\hline Q1 & 2.1 & 108 & 2.37 & 75.88 & 0.27 & -32.12 & 2.3 & 215 & 2.37 & 75.84 & 0.07 & -139.1 \\
\hline $\mathrm{K} 2$ & 4.9 & 98 & 6.11 & 93.31 & 1.21 & -4.69 & 5.1 & 90 & 6.16 & 93.37 & 1.06 & 3.37 \\
\hline \multirow[t]{3}{*}{$\mathrm{N} 2$} & 6.8 & 138 & 7.02 & 96.7 & 0.22 & -41.3 & 5.2 & 84 & 7.06 & 96.93 & 1.86 & 12.93 \\
\hline & \multicolumn{2}{|c|}{ Ponta do Ubu } & \multicolumn{2}{|c|}{ Gauge 05} & \multicolumn{2}{|c|}{ Error } & \multicolumn{2}{|c|}{ Barra do Itapemirim } & \multicolumn{2}{|c|}{ Gauge 06} & \multicolumn{2}{|c|}{ Error } \\
\hline & $\begin{array}{c}\text { Amp. } \\
(\mathrm{cm})\end{array}$ & $\begin{array}{c}\text { Phase } \\
\left({ }^{\circ}\right)\end{array}$ & $\begin{array}{c}\text { Amp. } \\
(\mathrm{cm})\end{array}$ & $\begin{array}{c}\text { Phase } \\
\left(^{\circ}\right)\end{array}$ & $\begin{array}{l}\text { Amp } \\
(\mathrm{cm})\end{array}$ & $\begin{array}{c}\text { Phase } \\
\left({ }^{\circ}\right)\end{array}$ & $\begin{array}{l}\text { Amp. } \\
(\mathrm{cm})\end{array}$ & $\begin{array}{c}\text { Phase } \\
\left({ }^{\circ}\right)\end{array}$ & $\begin{array}{l}\text { Amp } \\
(\mathrm{cm})\end{array}$ & $\begin{array}{c}\text { Phase } \\
\left({ }^{\circ}\right)\end{array}$ & $\begin{array}{l}\text { Amp } \\
(\mathrm{cm})\end{array}$ & $\begin{array}{c}\text { Phase } \\
\left({ }^{\circ}\right)\end{array}$ \\
\hline M2 & 45.1 & 90 & 46.6 & 88.56 & 1.5 & -1.44 & 42.1 & 95 & 49.18 & 88.45 & 7.08 & -6.55 \\
\hline $\mathrm{S} 2$ & 22.1 & 104 & 20.93 & 99.5 & -1.17 & -4.5 & 19.6 & 104 & 22.27 & 99.65 & 2.67 & -4.35 \\
\hline O1 & 7.7 & 102 & 8.89 & 101.19 & 1.19 & -0.81 & 8.1 & 210 & 9.08 & 101.6 & 0.98 & -108.4 \\
\hline K1 & 4.8 & 157 & 5.79 & 164.75 & 0.99 & 7.75 & 6.3 & 173 & 5.94 & 164.99 & -0.36 & -8.01 \\
\hline Q1 & 1.9 & 46 & 2.37 & 75.94 & 0.47 & 29.94 & 2 & 75 & 2.42 & 76.38 & 0.42 & 1.38 \\
\hline $\mathrm{K} 2$ & 6 & 105 & 6.2 & 93.42 & 0.2 & -11.58 & 5.3 & 104 & 6.6 & 93.48 & 1.3 & -10.52 \\
\hline $\mathrm{N} 2$ & 7.1 & 97 & 7.08 & 97.03 & -0.02 & 0.03 & 6.3 & 107 & 7.38 & 97.29 & 1.08 & -9.71 \\
\hline
\end{tabular}




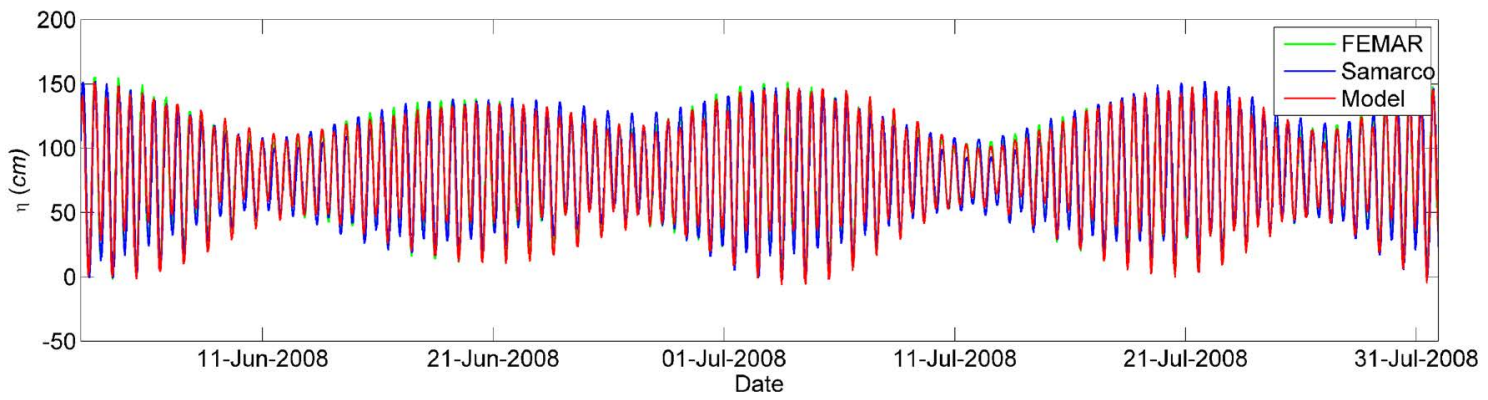

Figure 3. Time series of water level records at Ponta do Ubu. Samarco field data (blue line), numerical data (red line) and FEMAR (SALLES et al., 2000) data (green line).

The time series of water level recorded at Ponta de Ubu for the L1, L2 and L3 grids are shown in Figure 4.

The average error of the amplitude and phase was calculated by means of the average of the sum of the errors (MAE, Equation 1). The advantages of using the mean absolute error (MAE) instead of the root mean square error (RMSE) or related measurements the reader may find in WILLMOTT and MATSUURA (2005).

$$
M A E=\frac{1}{n} \sum_{i=1}^{n}\left|P_{i}-O_{i}\right|
$$

The model adjustment index (Equation 2), as proposed by WILLMOTT et al. (2012), was used to measure the model's performance, based on the ocean surface elevation (level) time series generated by the astronomical tide.

$d_{r}=\left\{\begin{array}{l}\frac{\sum_{i=1}^{n}\left|P_{i}-O_{i}\right|}{c \sum_{i=1}^{n}\left|O_{i}-\bar{O}_{i}\right|} \text {, if } \sum_{i=1}^{n}\left|P_{i}-O_{i}\right| \leq c \sum_{i=1}^{n}\left|O_{i}-\bar{O}\right| \\ \frac{C \sum_{i=1}^{n}\left|O_{i}-\bar{O}\right|}{\sum_{i=1}^{n}\left|P_{i}-O_{i}\right|}-1, \text { if } \sum_{i=1}^{n}\left|P_{i}-O_{i}\right|>c \sum_{i=1}^{n}\left|O_{i}-\bar{O}\right|\end{array}\right.$

This index corresponds to the improved version of the adjustment index $d=1-\sum_{1}^{n}\left(P_{i}-O_{i}\right)^{2} / \sum_{i}^{n}\left(\left|P_{i}-\bar{O}\right|+\left|O_{i}-\bar{O}\right|\right)^{2}$ proposed by WILLMOTT et al. (1985), and basically measures the magnitude of the differences between the observed data $\left(O_{i}\right)$ and the numerical data $\left(P_{i}\right)$ relative to the observed deviations from the observed mean $\bar{O}$ of a time series of a perfect-model. In the equations above, $n$ is the number of records and $c$ equals 2 as found by WILLMOTT et al. (2012).

The adjustment index has the advantage of having both an upper (1) and a lower limit (-1); other adjustment indices are bounded only by an upper limit (as is the case of the adjustment index $d$ itself). The upper and lower limits facilitate the evaluation of the error, especially in the case of models with low performance (SARACENO et al., 2011). More information and interpretation details pertaining to this index have been described by WILLMOTT et al. (2012).

The $\mathrm{d}_{\mathrm{r}}$ calculated between the predicted time series with harmonics provided by FEMAR (SALLES et al., 2000) and the model results is equal to 0.93 ; for comparison, the adjustment index (WILLMOTT et al., 1985) calculated for the same time series was equal to 0.99 . For the time series generated from the harmonics extracted from the measured time series (SAMARCO), the calculated $d_{r}$ was equal to 0.84 and the adjustment index was equal to 0.97 . The calculated MAE was equal to $7.5 \mathrm{~cm}$ for the comparison between the numerical results and the data from FEMAR (SALLES et al., 2000), and $10.5 \mathrm{~cm}$ for the comparison between model results and the time series predicted from the measured data (SAMARCO data). A summary of the statistical parameters are shown in Table 4.

The root mean square error misfit statistical parameter (Equation 3) was used to quantify the error given the phase-amplitude, as in SARACENO et al. (2011) and MATSUMOTO (2000).

$$
R M S E_{\text {MSFT }}=\left(\begin{array}{c}
\left.\frac{1}{n} \sum_{i=1}^{n}\left[H_{1} \cos \left(g_{1}\right)-\mathrm{H}_{2} \cos \left(g_{2}\right)\right]^{2}\right)^{1 / 2} \\
+\left[\mathrm{H}_{1} \sin \left(g_{1}\right)-\mathrm{H}_{2} \sin \left(g_{2}\right)\right]^{2}
\end{array}\right.
$$

The magnitude of the MAE for the phase and amplitude, RMSE Misfit and percentage of the error for the tide harmonics for all measuring stations are shown in Figure 5.

The tide harmonics and ellipses were calculated for the entire study region for the two semi-diurnal harmonics with the largest amplitude (M2 and S2) and for the two diurnal harmonics with the largest amplitude (O1 and K1) for a simulated period equivalent to approximately 120 tide periods.

The co-tidal and ellipse tidal maps for the M2 semi-diurnal tide harmonic are shown in Figures 6 and 7, respectively. The 


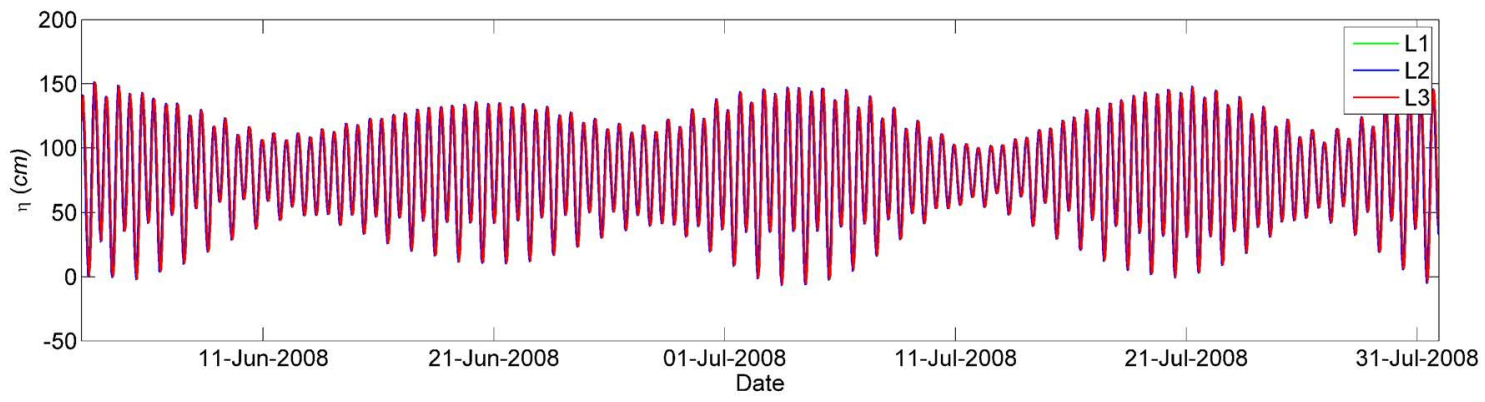

Figure 4. Time series of water level records at Ponta do Ubu for the grids: L1 (green line), L2 (blue line) and L3 (red line).

Table 4. Statistical indices comparing the model results with FEMAR (SALLES et al., 2000) data and measured data (SAMARCO).

\begin{tabular}{lcc}
\hline Statistics & $\begin{array}{c}\text { Model } v s . \\
\text { FEMAR }\end{array}$ & $\begin{array}{c}\text { Model } v s . \\
\text { SAMARCO }\end{array}$ \\
\hline $\mathrm{d}_{\mathrm{r}}$ (Willmott et al., 2012) & 0.84 & 0.97 \\
$\mathrm{~d}$ (Willmott et al., 1985) & 0.93 & 0.99 \\
MAE & $7.5 \mathrm{~cm}$ & $10.5 \mathrm{~cm}$ \\
\hline
\end{tabular}
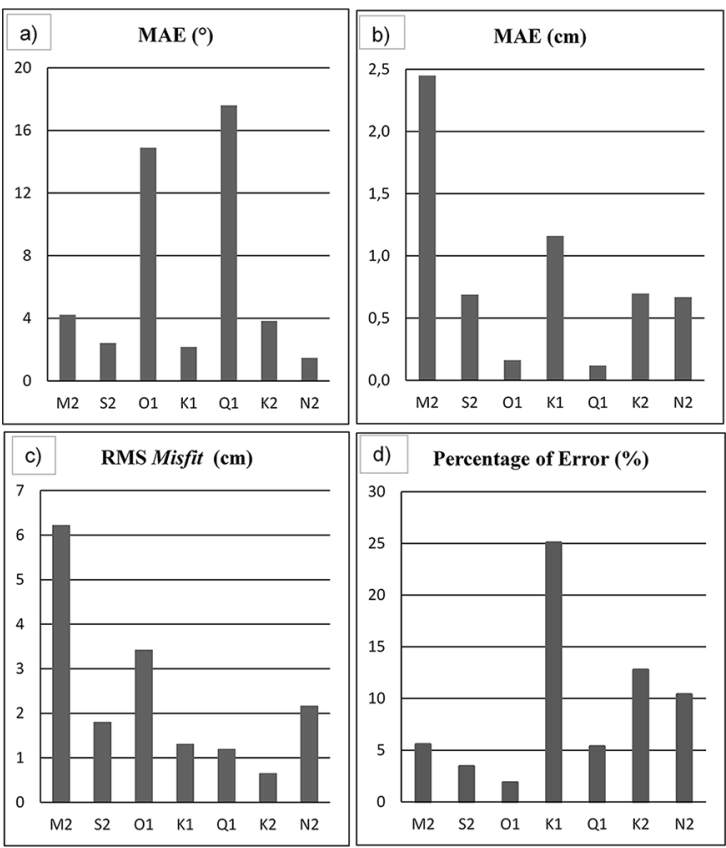

Figure 5. Statistical parameters between numerical results and the data provided by FEMAR considering only the seven principal harmonics. Mean absolute error (MAE) for both the amplitude (a) and phase (b), root mean square error misfit (c), and Percentage of Error (d).

second semi-diurnal harmonic with the largest amplitude in the study region is represented by the S2 harmonics; the amplitudes and phases of this harmonic are shown in Figure 8, and its ellipses are shown in Figure 9.

Within the diurnal band of the tide spectrum, the $\mathrm{O} 1$ harmonic component had the largest amplitude in the study region. The amplitudes and phases of this harmonic are shown in Figure 10, and its ellipses are shown in Figure 11. For the $\mathrm{K} 1$ harmonic, the tidal phases and amplitudes are shown in Figure 12, and their ellipses are shown in Figure 13.

The time series of space integrated potential and kinetic energy (over the study area) are shown in Figure 14. Maps of energy per unit area (Equation 4) integrated over the simulated period of two months are shown in Figure 15.

$E_{T}=\int_{s} \frac{1}{2} p h\left(U^{2}+V^{2}\right) d S+\frac{\int}{s} \frac{1}{2} p n \eta^{2} d S$

The first integral on the right-hand side of Equation 4 quantifies the kinetic energy and the second integral provides a measure of potential energy, both of them generated by the astronomical tide in a specific area $S$ (LONGUET-HIGGINS, 1968). In Equation 4, $\rho$ is the specific mass of sea water, $U$ and $V$ are the depth averaged horizontal velocities, $\eta$ is the displacement of the free surface, $h$ is the mean water depth, $g$ is the acceleration due to gravity and $d S$ is the differential of area.

Finally, the tidal residual currents induced by the tide were integrated for a period of approximately 120 tide cycles or 1440 hours (Figure 16).

\section{DISCUSSION}

\section{Model Validation}

In environmental modelling, choosing the best statistical method is one of the biggest challenges when assessing model performance. Generally, the average behaviour of the error is measured using the root mean square error, which is based on the square of the sums of the errors; however, this parameter not only describes the average error but also tends to have higher magnitudes than other statistical parameters, such as the MAE (WILLMOTT; MATSUURA, 2005).

In this paper, the MAE was calculated to describe the behavior of the errors associated with the comparison 


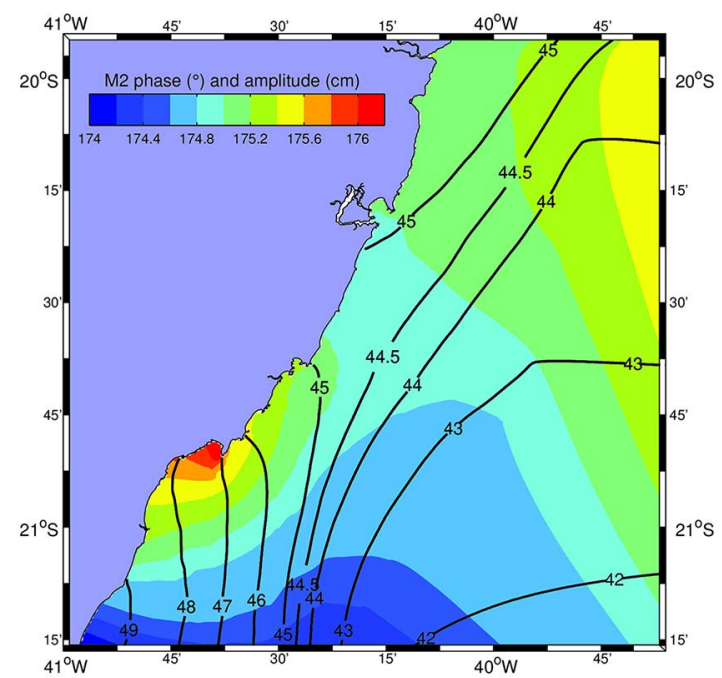

Figure 6. Amplitudes (black full lines) in $\mathrm{cm}$ and phases (filled contours) in degrees relative to Greenwich for the M2 component.

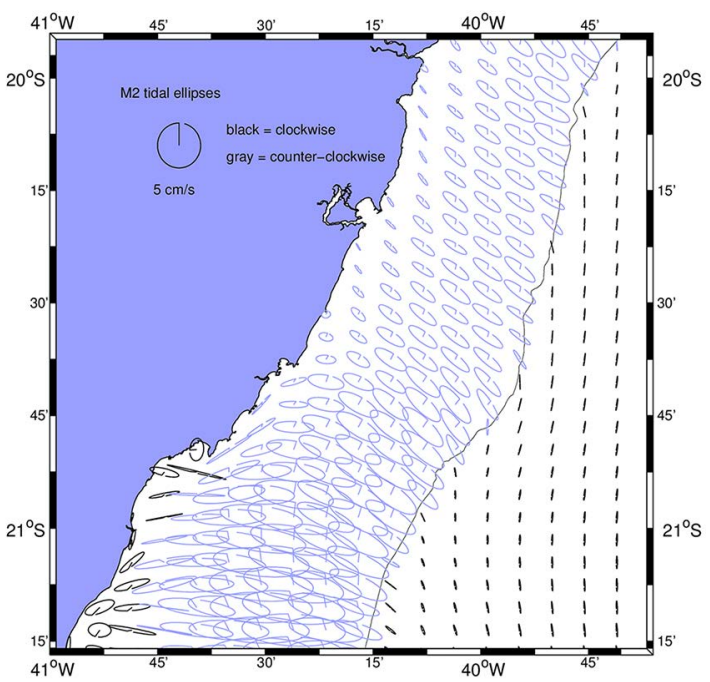

Figure 7. Tidal ellipses for the M2 semidiurnal component. The 200 $\mathrm{m}$ isobath represents the continental shelf break.

between the amplitude and phase resultant from the numerical model and that calculated by the tidal gauges. The largest amplitude error was associated with the semi-diurnal M2 harmonic $(2.5 \mathrm{~cm})$; whereas for the other analysed harmonics the error is less than $1.2 \mathrm{~cm}$, as shown in Figure 5a. The phases with the largest errors are related to the diurnal harmonics $\mathrm{O} 1$ and Q1 $\left(15.6^{\circ}\right.$ and $17^{\circ}$, respectively); for the other harmonics this error was less than $4^{\circ}$ (Figure $5 b$ ).

The maximum RMSE Misfit values (Figure 5c) were associated with the harmonics with the largest amplitude: M2 (RMSE Misfit error of $6.2 \mathrm{~cm}$ or $5.5 \%$ of error) and S2

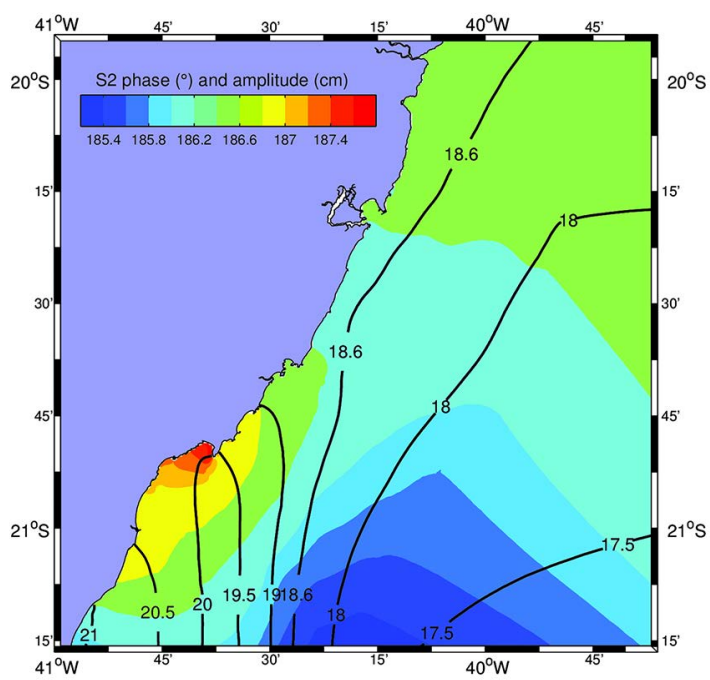

Figure 8. Amplitudes (black full lines) in $\mathrm{cm}$ and phases (filled contours) in degrees relative to Greenwich for the S2 component.

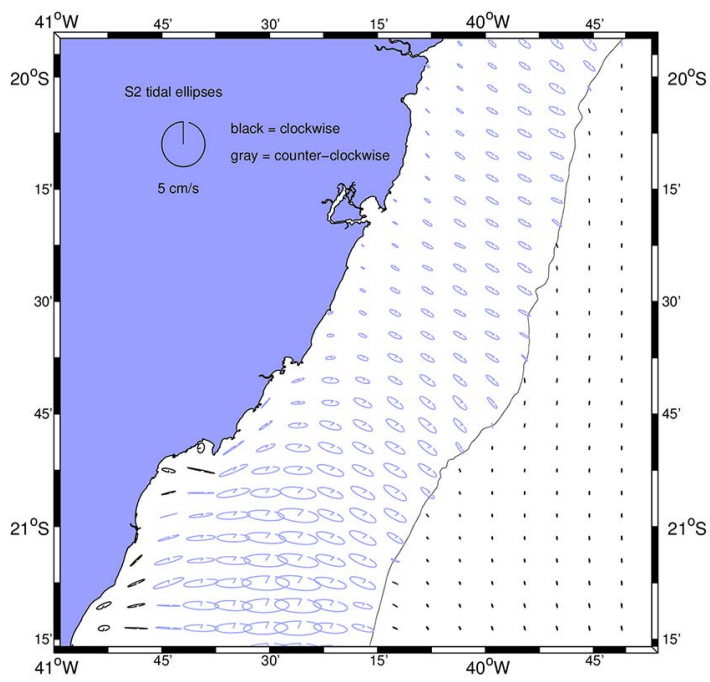

Figure 9. Tidal ellipses for the S2 semidiurnal component. The $200 \mathrm{~m}$ isobath represents the continental shelf break.

(RMSE Misfit error of $1.72 \mathrm{~cm}$ or $3.4 \%$ of error), as shown in Figure $5 \mathrm{~d}$. These values are lower than those found by SARACENO et al. (2011) in an analysis of coastal stations and tide models on the Patagonian shelf.

The comparison between the harmonics calculated by the numerical model and the harmonics provided by FEMAR shows a reasonable adjustment (Table 3). The largest error amplitudes were found at the Barra do Itapemirim station ( $7 \mathrm{~cm}$ for $\mathrm{M} 2$ and $3 \mathrm{~cm}$ for $\mathrm{S} 2$ ); the amplitude error average was $2.5 \mathrm{~cm}$ for the $\mathrm{M} 2$ harmonic component and less than $1.2 \mathrm{~cm}$ for the other analysed harmonics. These discrepancies can be attributed to local 


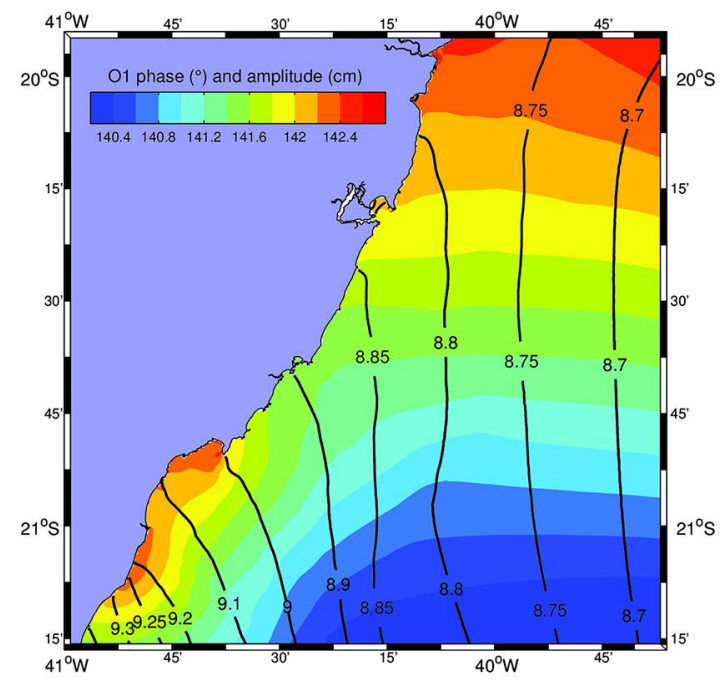

Figure 10. Amplitudes (black full lines) in $\mathrm{cm}$ and phases (filled contour) in degrees relative to Greenwich for the $\mathrm{O} 1$ harmonic component.

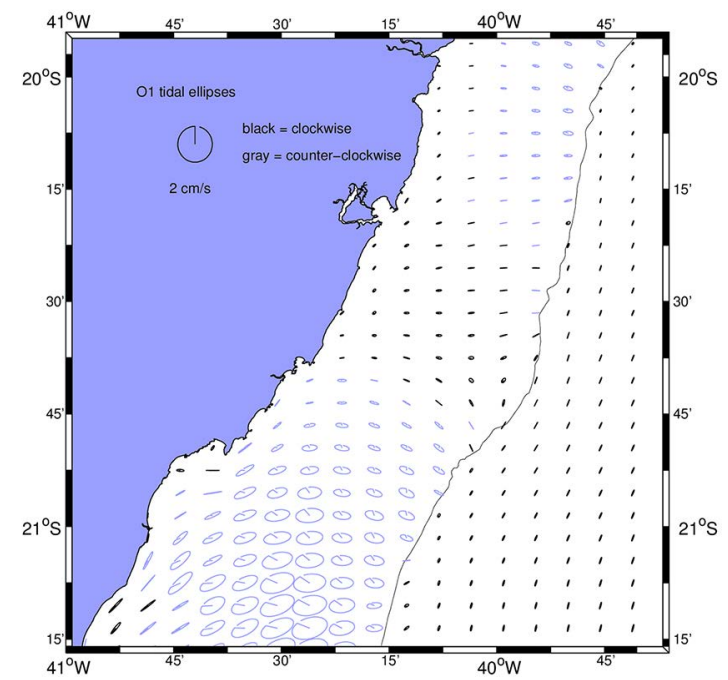

Figure 11. Tidal ellipses for the $\mathrm{O} 1$ diurnal component. The $200 \mathrm{~m}$ isoline represents the continental shelf break.

effects (such as the presence of rivers) that are not represented in the numerical model, since a large proportion of the tide stations provided by FEMAR are located near the mouth of rivers. The interactions between the tide wave and local bathymetry might also explain these discrepancies.

In addition to the river issue, one must address the short time series on which the harmonic constants generated by FEMAR (SALLES et al., 2000) are based (approximately one month of measurements for the stations located in the study region). HARARI and CAMARGO (2003) observed that the results generated from a 46-year-long time series were significantly different from those produced by FEMAR in one year.

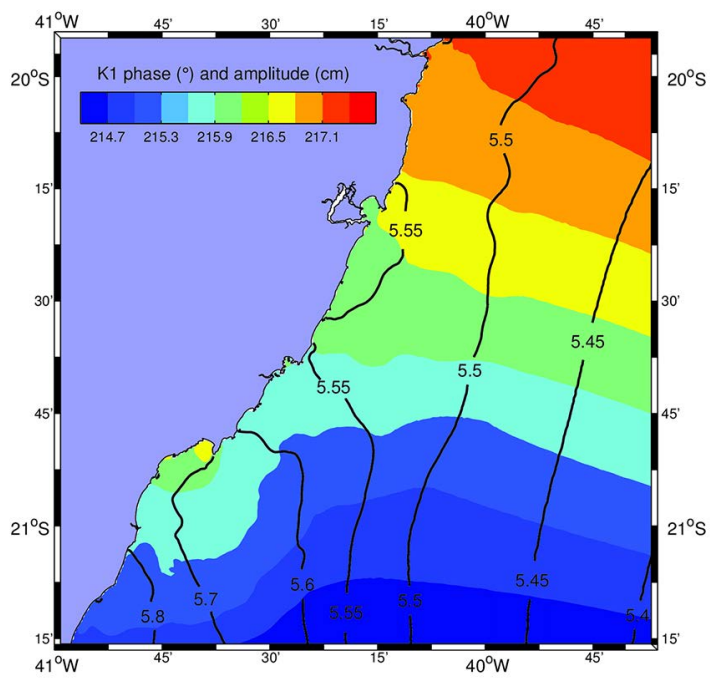

Figure 12. Amplitudes (black full lines) in $\mathrm{cm}$ and phases (filled contours) in degrees relative to Greenwich for the $\mathrm{K} 1$ component.

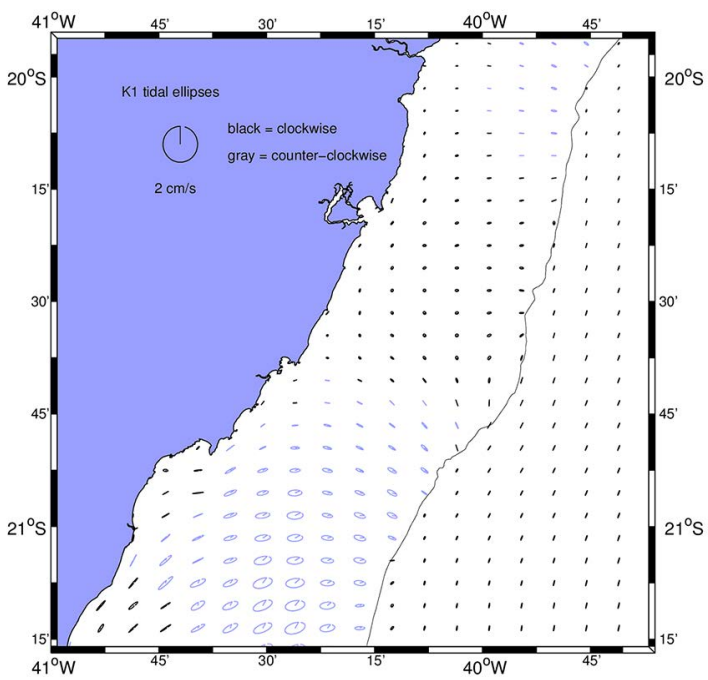

Figure 13. Tide ellipses for the $\mathrm{K} 1$ diurnal component. The $200 \mathrm{~m}$ isoline represents the continental shelf break.

The main tide harmonics for the Port of Ubu generated by FEMAR (SALLES et al., 2000) were compared with data measured in the field and with results from the numerical model (Table 5). Significant differences were noted, primarily for the $\mathrm{N} 2$ semi-diurnal harmonics $(7 \mathrm{~cm})$ and the $\mathrm{O} 1$ diurnal harmonics $(3 \mathrm{~cm})$, even though this tide station is not even near any river and/or embayment; these discrepancies may be related to the length of the time series used by FEMAR (SALLES et al., 2000) to estimate tide harmonics (in this case, one month).

The adjustment index considering the FEMAR harmonics (0.93) and the measured data (0.87) for the Port of Ubu station shows that the model can satisfactorily capture the elevations 
Spatial means of Potential, Kinetic and Total Energy $\left(\mathrm{J} / \mathrm{m}^{2}\right)$
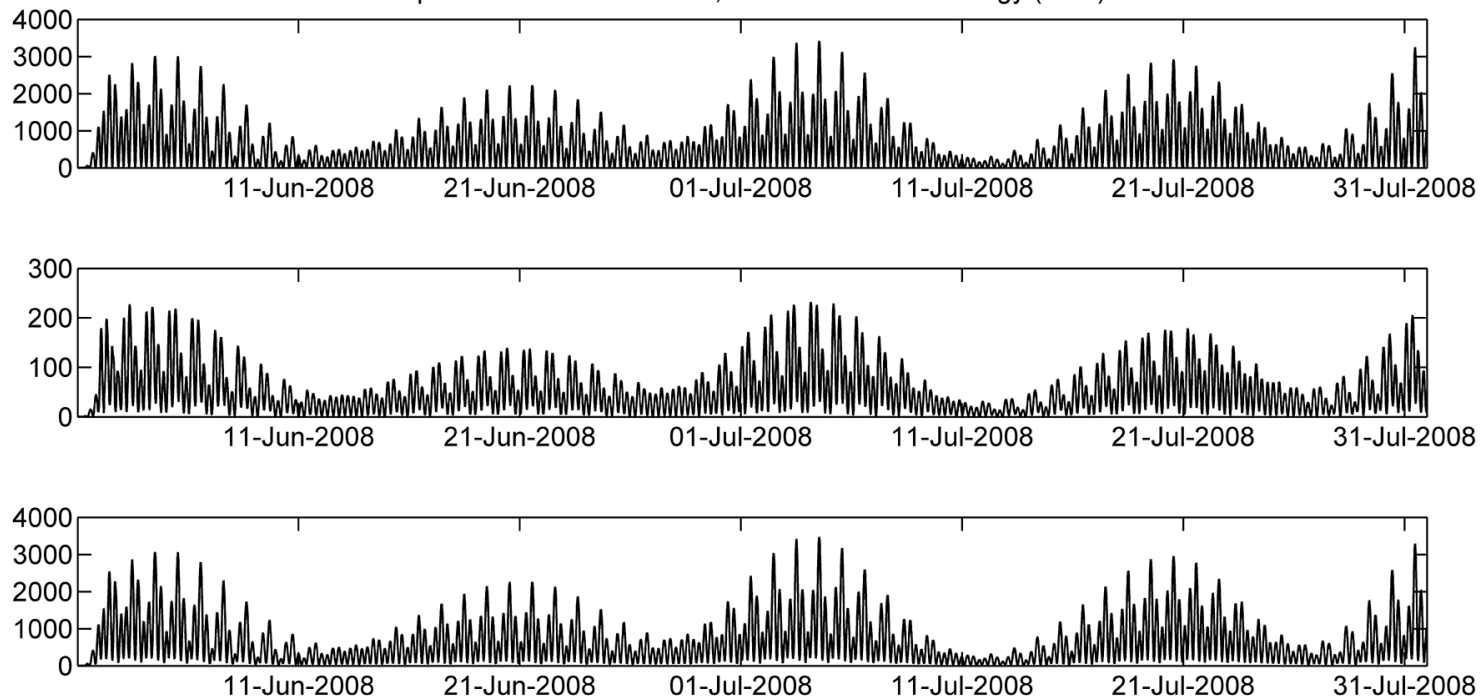

Figure 14. Time serie evolution of the spatial averages of potential, kinetic and total energy for the study region. Units $\mathrm{J} / \mathrm{m}^{2}$.
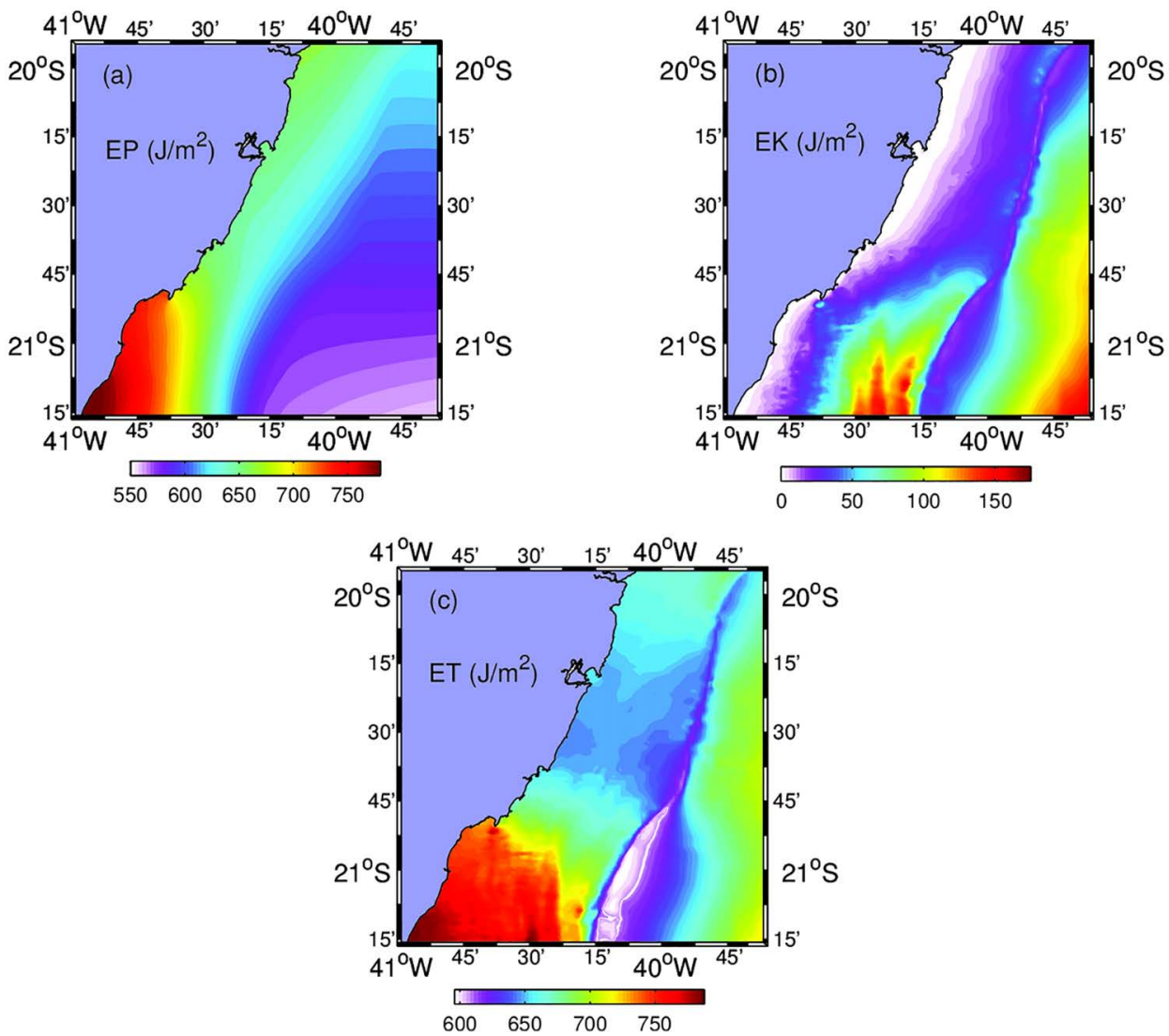

Figure 15. Time integrated energy per unit of area for an integration period of 120 tide cycles (1440 hours). In (a), the potential energy, in (b), the kinetic energy and in (c), the total energy. Units in $\mathrm{J} / \mathrm{m}^{2}$. 


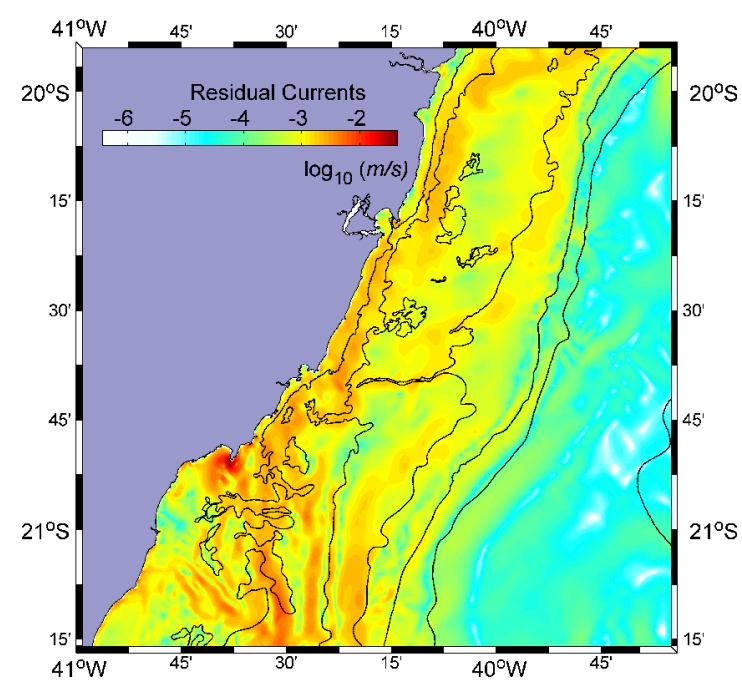

Figure 16. Residual currents calculated for a period corresponding to 120 tide cycles (1440 hours) in $\log 10$ scale. The contour lines correspond to the $20 \mathrm{~m}, 30 \mathrm{~m}, 50 \mathrm{~m}, 1000 \mathrm{~m}$ and $2000 \mathrm{~m}$ isobaths.

generated by the astronomical tide; similar conclusions were drawn when the time series generated by the numerical model, tide predictions and field data were compared (Figure 3).

Despite the different resolution for the L1, L2 and L3 domains the time history of the water level recorded at the Ponta do Ubu for the three grids have the same behaviour, see Figure 4. A maximum absolute error of $3 \mathrm{~cm}$ is found among the records when the water level history of the $\mathrm{L} 3$ domain is chosen as a reference.

\section{Semi-Diurnal Tidal Components}

The behavior of the semi-diurnal components is represented in this study by the two main harmonics that exhibit this behavior within the tidal spectrum in the study area (M2 and S2). The model results show that the amplitude of the M2 tidal component varies from $41.5 \mathrm{~cm}$ to $49.2 \mathrm{~cm}$ throughout the study area, and this component represents the most energetic component within the tide spectrum of the study region (Figure 6).

The M2 harmonic component is essentially progressive, with phase variations between $174^{\circ}$ and $176.2^{\circ}$ and propagation in the southwest-northeast direction. It is well known that the behavior of oceanic tides approaches the shallow water wave velocity $c=\sqrt{g H}$, but in shallow seas the behavior of the tides is driven by co-oscilations of the oceanic tides, e.g., for a depth of $2000 \mathrm{~m}$ the shallow water wave velocity is $\sim 140 \mathrm{~m} / \mathrm{s}$, while the tidal wave velocity estimated by means of the phase lag is about $280 \mathrm{~m} / \mathrm{s}$.

The distribution of the M2 harmonic component phases (Figure 6) shows that there exists a phase lag south of Guarapari; this lag is likely related to the presence of Ponta do Ubu (an approximately 2.5 -km-long rocky/sandy promontory and the northern end of an approximately 30-km-long beach arc) and the adjacent bathymetry.

The largest amplitudes and amplitude gradients of the M2 harmonic component are also found to the south of Ponta do Ubu, varying from $46 \mathrm{~cm}$ to $49.2 \mathrm{~cm}$. This phenomenon is most likely related to the amplification caused by the continental shelf's length - of approximately $65 \mathrm{~km}$ - to the south of this region; indeed, as shown by BATTISTI and CLARKE (1982), QUARESMA and PICHON (2013), the length of the continental shelf determines the tide amplification.

The maximum magnitude of the major semi-axis of the tidal ellipses for the M2 harmonic component was approximately $20 \mathrm{~cm} / \mathrm{s}$. This value was found on the inner and middle shelf to the south of Ponta do Ubu in response

Table 5. Tide harmonics provided by FEMAR (SALLES et al., 2000), calculated from the data measured in the field and generated by the numerical model.

\begin{tabular}{|c|c|c|c|c|c|c|c|c|c|c|}
\hline & \multicolumn{2}{|c|}{ FEMAR (2000) } & \multicolumn{2}{|c|}{ Samarco } & \multicolumn{2}{|c|}{ Model } & \multicolumn{2}{|c|}{ Error (Model-FEMAR) } & \multicolumn{2}{|c|}{ Error (Model-Samarco) } \\
\hline & $\begin{array}{l}\text { Amp. } \\
(\mathrm{cm})\end{array}$ & Phase $\left(^{\circ}\right)$ & $\begin{array}{l}\text { Amp. } \\
(\mathrm{cm})\end{array}$ & Phase $\left(^{\circ}\right)$ & $\begin{array}{l}\text { Amp. } \\
(\mathrm{cm})\end{array}$ & Phase $\left({ }^{\circ}\right)$ & $\begin{array}{l}\text { Amp. } \\
(\mathrm{cm})\end{array}$ & Phase $\left(^{\circ}\right)$ & $\begin{array}{l}\text { Amp. } \\
(\mathrm{cm})\end{array}$ & Phase $\left(^{\circ}\right)$ \\
\hline M2 & 45.1 & 90 & 45.87 & 101.78 & 45.96 & 88.49 & 0.86 & -1.51 & 0.09 & -13.29 \\
\hline S2 & 22.1 & 104 & 21.43 & 114.31 & 19.19 & 101.35 & -2.91 & -2.65 & -2.24 & -12.96 \\
\hline $\mathrm{O} 1$ & 7.7 & 102 & 10.42 & 110.3 & 8.92 & 100.15 & 1.22 & -1.85 & -1.5 & -10.15 \\
\hline K1 & 4.8 & 157 & 5.91 & 158.91 & 6.07 & 170.06 & 1.27 & 13.06 & 0.16 & 11.15 \\
\hline Q1 & 1.9 & 46 & 2.94 & 90.15 & 2.5 & 74.72 & 0.6 & 28.72 & -0.44 & -15.43 \\
\hline $\mathrm{K} 2$ & 6.0 & 105 & 7.93 & 93.92 & 5.03 & 83.39 & -0.97 & -21.61 & -2.9 & -10.53 \\
\hline $2 \mathrm{~N} 2$ & 0.9 & 103 & 8.01 & 107.93 & 6.57 & 95.06 & 5.67 & -7.94 & -1.44 & -12.87 \\
\hline P1 & 1.6 & 153 & 2.42 & 96.9 & 0.6 & 335.28 & -1 & 182.28 & -1.82 & 238.38 \\
\hline M4 & 1.1 & 76 & 1.67 & 147.56 & 1.29 & 138.11 & 0.19 & 62.11 & -0.38 & -9.45 \\
\hline
\end{tabular}


to the amplification induced by the continental shelf's width in this region; smaller magnitudes are associated with the offshore regions of the continental shelf (continental slope). The maximum magnitude of the minor semi-axis is approximately $3 \mathrm{~cm} / \mathrm{s}$; this finding also appears to be related to the continental shelf's width to the south of Ponta do Ubu (Figure 7).

The tidal ellipses for the M2 harmonic component are shown in Figure 7 . In the region offshore to the shelf break (marked in Figure 6 by the $200 \mathrm{~m}$ isobath), the ellipses present very small magnitudes and are essentially aligned with the north-south axis, with a clockwise rotation. Over the continental shelf, the ellipses are oriented approximately perpendicularly to the coast; the continental shelf is also responsible for the polarisation of the ellipses in the counterclockwise direction.

South of Ponta do Ubu, near the coast, the ellipses behave in a distinct way; in particular, the rotation of the ellipses changes direction (clockwise). This behaviour is most likely related to the local geometry and bathymetry.

The distribution of the amplitudes and phases of the S2 harmonic component is similar to that of the M2 component. QUARESMA and PICHON (2013) have shown that this similar behavior for harmonics in the same tide spectrum band is associated with the inertial period $(\sim 34.3 \mathrm{~h}$ for the study area).

For latitudes north to $30^{\circ} \mathrm{N}$ and south to $30^{\circ} \mathrm{S}$, the inertial period splits the two primary bands of the tide spectrum into two distinct groups: a supra-inertial group (diurnal components) and a sub-inertial group (semi-diurnal components). Therefore, the semi-diurnal harmonics M2, S2, K2 and N2 behave in a similar way; only small differences in the magnitude of phases and amplitudes and in the cotidal lines are detectable. In an analogous way, the diurnal harmonics $\mathrm{O} 1, \mathrm{~K} 1, \mathrm{Q} 1$ and $\mathrm{P} 1$ show the same behavior.

However, the study area is located between latitude $19.8^{\circ} \mathrm{S}$ and $21.2^{\circ} \mathrm{S}$ and has an inertial period between 33.26 $\mathrm{h}$ and $35.43 \mathrm{~h}$. As the semi-diurnal harmonics have a period of $12 \mathrm{~h}$ and the diurnal harmonics have a period of $24 \mathrm{~h}$, the primary harmonics are not divided into supra-inertial and sub-inertial groups for this study region (both the semidiurnal and diurnal harmonics are sub-inertial).

BATTISTI and CLARKE (1982) have shown how velocity and elevation are related to the frequency of the tide harmonics. Therefore, the similar behavior of the semi-diurnal harmonics ( $23 \mu \mathrm{Hz}$ frequency band) in the study region is most likely related to the fact that these tide harmonics are located within the same frequency band of the tide spectrum. The diurnal harmonics (12 $\mu \mathrm{Hz}$ frequency band) also behave in a similar way.

The S2 harmonic component is progressive in the region beyond the continental shelf, with the southwestnortheast propagation direction and phase varying between $185.2^{\circ}$ and $187.8^{\circ}$. The amplitude of the S2 component varies from $17.4 \mathrm{~cm}$ to $21 \mathrm{~cm}$ throughout the region. The largest amplitudes are located to the south of Ponta do Ubu (between $19.5 \mathrm{~cm}$ and $21 \mathrm{~cm}$ ). A phase lag in the distribution of phases and amplitudes of this harmonic component can also be observed in the region (where the largest phase magnitudes are also found) (Figure 8).

Like the M2 component, the tide ellipses of the S2 harmonic component (Figure 9) appear to be polarised by the presence of the continental shelf; as a result, the ellipses rotate in a different direction (counter-clockwise) from that presented outside the continental shelf. In addition, the orientation of the ellipses changes in this region (perpendicular to the coast).

The maximum magnitude of the major semi-axis of the tide ellipses was equal to $8 \mathrm{~cm} / \mathrm{s}$ ( $40 \%$ of the harmonic component magnitude corresponding to M2) and the minor semi-axis was $1 \mathrm{~cm} / \mathrm{s}$. These magnitudes are found over the continental shelf to the south of Ponta do Ubu. The ellipses in the coastal region to the south of Ponta do Ubu are also oriented in a clockwise direction.

\section{DiURnal Tidal COMPONENTS}

The diurnal harmonic components are located in the 12 $\mu \mathrm{Hz}$ band of the tidal spectrum and also behave in a similar way. In this study the harmonics of greatest amplitude of this spectrum band for the study area are $\mathrm{O} 1$ and $\mathrm{K} 1$.

The O1 tidal component has the largest amplitude within the spectrum band corresponding to the diurnal harmonics; the amplitude of this harmonic component varies from $8.7 \mathrm{~cm}$ to $9.4 \mathrm{~cm}$ for the entire study region. The co-tidal distribution (Figure 10) shows that the tidal wave corresponding to the $\mathrm{O} 1$ tidal component is essentially progressive throughout the entire simulation domain and travels from south to north. The phase varies from $140.2^{\circ}$ to $142.4^{\circ}$, and to the south of Ponta do Ubu the largest phase lags $\left(142^{\circ}-142.4^{\circ}\right)$, amplitudes and amplitude gradients are found.

With the exception of the coastal region south of Ponta do Ubu, the distribution of co-phases and co-amplitudes shows that the co-phase lines are parallel to the latitudes, while the co-amplitude lines are almost orthogonal to the latitudes (Figure 10). 
The tidal ellipses for the $\mathrm{O} 1$ harmonic component (Figure 11) have a different polarisation over the continental shelf: to the south of Guarapari, the ellipses rotate in a counter-clockwise direction; between Guarapari and Vitória, the ellipses rotate in a clockwise direction throughout the shelf; to the north of Vitória, as far out as a depth of $30 \mathrm{~m}$ the ellipses rotate in a clockwise direction; and over the rest of the continental shelf the ellipses rotate in a counter-clockwise direction.

The largest magnitudes of the ellipses are located on the middle continental shelf south of the Ponta do Ubu. In this region, the magnitude of the major and minor semi-axis of the nearly circular ellipses reaches $2.4 \mathrm{~cm} / \mathrm{s}$ and $1.2 \mathrm{~cm} / \mathrm{s}$, respectively. North of Ponta do Ubu, the ellipses assume a more flattened aspect perpendicular to the isobaths; this suggests that in this region the axes of the largest tidal currents are orthogonal to the coastline.

The K1 harmonic component behaves in a similar way to the $\mathrm{O} 1$ tidal component. As shown in Figure 12, the co-phases are essentially orthogonal to the coastline and the co-amplitude lines are parallel to the isobaths. The amplitudes in the study area vary from $5.3 \mathrm{~cm}$ to $5.9 \mathrm{~cm}$, with the largest amplitudes situated to the south of Ponta do Ubu; in this region, the amplification of the tidal wave is detected by the distribution of phases and amplitudes (Figure 12). As the $\mathrm{O} 1$ behavior, co-phases of the $\mathrm{K} 1$ harmonic component range from $214^{\circ}$ to $217.8^{\circ}$ and are propagated from the southwest to the northeast.

The tidal ellipses of the K1 tidal component (Figure 13) follow a distribution similar to that of the $\mathrm{O} 1$ tidal harmonics; however, the major and minor semi-axes have maximal magnitudes of $1.3 \mathrm{~cm} / \mathrm{s}$ and $0.6 \mathrm{~cm} / \mathrm{s}$, respectively; these values are found on the middle continental shelf to the south of Ponta do Ubu. The polarisation of the ellipses follows the same distribution as that of the $\mathrm{O} 1$ tidal component.

\section{RESIDUAL CIRCULATION AND TIDAL ENERGY}

The time evolution of the energy (kinetic, potential and total) is shown in Figure 14. The energy grows until the equilibrium of the numerical model is reached. This indicates that the boundary condition imposed on the model permits the propagation of energy (both entering and exiting) in the simulation domain.

As shown by HARARI and CAMARGO (2003), a contrast exists between the spring and neap tides; the largest energy values occur in the spring tide periods, with values up to 10 times the maximum energy found in neap tide periods (Figure 14).
The time integrated kinetic energy (Figure 15a) for the study area varies from $5 \mathrm{~J} / \mathrm{m}^{2}$ to $160 \mathrm{~J} / \mathrm{m}^{2}$, with spatial distribution that follows the bathymetric contours. The potential energy (Figure 15b) has a similar distribution to that observed for the amplitudes of the semi-diurnal tide harmonics, with magnitudes varying from $550 \mathrm{~J} /$ $\mathrm{m}^{2}$ to $780 \mathrm{~J} / \mathrm{m}^{2}$. In the study region, the shape factor $f=(O 1+K 1) /(M 2+S 2)$ calculated from the model results varies from 0.21 to 0.24 , and is characteristic of a semi-diurnal tide regime. As the potential energy distribution is basically controlled by the elevation, which, in turn, is controlled by the semi-diurnal harmonics, the distribution of potential energy is similar to the spatial distribution of the semi-diurnal amplitudes. A similar phenomenon has been observed by HARARI and CAMARGO (2003).

The total energy in the study area (Figure 15c), corresponding to the sum of kinetic and potential energy, varies from $600 \mathrm{~J} / \mathrm{m}^{2}$ to $780 \mathrm{~J} / \mathrm{m}^{2}$. The largest magnitudes are found on the continental shelf to the south of Ponta do Ubu, and the potential energy dominates the energy distribution throughout the study area. Along the shelf break, a large decrease in energy occurs, most likely related to the reflection of energy caused by the continental slope and the abrupt change in depth between the continental shelf and slope.

Figure 16 illustrates the spatial behavior of the residual currents along the study area. The largest magnitudes (of the order of $5 \mathrm{~cm} / \mathrm{s}$ ) are found near Ponta do Ubu. It is likely that a large phase difference between the ebb and flood tide occurs in this region, caused by the presence of Ponta do Ubu. Residual currents of the order of $1 \mathrm{~cm} / \mathrm{s}$ are found between the 20 and $30 \mathrm{~m}$ isobaths; in the rest of the study area, the residual velocities are nearly zero.

\section{CONCLUSION}

In this study, the kinematic behavior of the astronomical tides on the continental shelf of Espírito Santo State is described. The model results are consistent with the measured data and those provided by FEMAR (SALLES et al., 2000). Nevertheless, the data provided by FEMAR present some discrepancy as compared to the measured data, due to the size of the series used for the harmonic analysis.

In general, the results show that semi-diurnal and diurnal tidal components have similar behavior. The semi-diurnal components, M2 and S2, have the same pattern of distribution for amplitudes and phases, both of them being progressive and propagating from 
southwest to northeast. Also, the ellipses of these semi-diurnal components (Figure 8) have maximum amplitudes of $20 \mathrm{~cm} / \mathrm{s}$ and $8 \mathrm{~cm} / \mathrm{s}$, respectively, for the M2 and S2 tidal harmonics, and appear to be polarised by the presence of the continental shelf, having a counter-clockwise rotation over the continental shelf and clockwise rotation beyond it.

Like the semi-diurnal tidal components, the $\mathrm{O} 1$ and K1 diurnal components also have the same behavior and their propagation is from southwest to northeast. The tidal ellipses of the harmonic $\mathrm{K} 1$ follow a similar distribution to the $\mathrm{O} 1$ tidal harmonic. The major and minor semi-axes of the ellipse have maximum magnitudes of $1.3 \mathrm{~cm} / \mathrm{s}$ and $0.6 \mathrm{~cm} / \mathrm{s}$, respectively; these values are found on the middle continental shelf south of Ponta do Ubu.

The total tidal energy varies from $600 \mathrm{~J} / \mathrm{m}^{2}$ to 780 $\mathrm{J} / \mathrm{m}^{2}$ throughout the domain, the largest magnitudes of total energy being found on the continental shelf to the south of Ponta do Ubu, with the potential energy dominating the energy distribution throughout the study area. In relation to the residual currents, the largest magnitudes are found near Ponta do Ubu, reaching $0.03 \mathrm{~m} / \mathrm{s}$, while in the rest of the study area the residual velocities are nearly zero.

The greatest phase lags and the largest amplitudes of the analysed tide harmonics are found in the region adjacent to Ponta do Ubu. The continental shelf also appears to be responsible for the polarisation of the tidal ellipses; indeed, near the coast to the south of Ponta do Ubu the tidal ellipses behave differently from the ellipses observed all over the rest of the continental shelf.

The continental slope appears to be responsible for the reflection of the tidal wave and the decrease in the kinetic energy in this region. The distribution of potential energy follows a similar pattern as the spatial distribution of the amplitude of the semi-diurnal tidal harmonics.

The model implemented in the study region was able to satisfactorily reproduce the astronomical tide with minimal error, and can be used in engineering and environmental studies.

\section{REFERENCES}

ARAKAWA, A. Computational design for long-term numerical integration of the equations of fluid motion: Twodimensional incompressible flow - Part I. J. Comput. Phys., v. 135 , n. 1, p. 103-114, 1997.
BATTISTI, D. S.; CLARKE, A. J. A simple method for estimating barotropic tidal currents on continental margins with specific applications to the M2 tide off the Atlantic and Pacific coasts of the United States. J. Phys. Oceanogr., v. 12, n. 1, p. 8-16, 1982.

CAMARGO, R.; HARARI, J. Modeling the Paranagua Estuarine Complex, Brazil: tidal circulation and co-tidal charts. Rev. Bras. Oceanogr., v. 51, n. 1, p. 23-31, 2003.

DELHEZ, E.; DELEERSNIJDER, E. Overshootings and spurious oscillations caused by biharmonic mixing. Ocean Model., v. 17, n. 3, p. 183-198, 2007.

EGBERT, G. D.; EROFEEVA, S. Y. Efficient inverse modeling of barotropic ocean tides. Am. Meteorol. Soc., v. 19, p. 183-204, 2002.

FERNANDES, A. M.; SILVEIRA, I. C. A.; CALADO, L.; CAMPOS, E. J. D.; PAIVA, A. M. A two-layer approximation to the Brazil Current-Intermediate Western Boundary Current System between $20^{\circ} \mathrm{S}$ and $28^{\circ} \mathrm{S}$. Ocean Model., v. 29, n. 2, p. 154-158, 2009.

FLATHER, R. A. A tidal model for the northwest European continental shelf. Mém. Soc. R. Sci. Liège, v. 10, p. 141-164, 1976.

FRANCO, A. S. Tides - fundamentals, analysis and prediction. Public. FCTH Fundação Centro Tecnológico de Hidráulica. 2.ed. São Paulo: Escola Politécnica da USP, 1988. 249 p.

FRANCO, A. S.; HARARI, J. Computer programs for tidal data checking, correction, analysis and prediction by the harmonic method. Relat. Int. Inst. oceanogr., Univ. S. Paulo, 16: 1-65, 1987.

HARARI, J.; CAMARGO, R. Simulação da propagação das nove principais componentes de maré na plataforma sudeste brasileira através de modelo numérico hidrodinâmico. Bol. Inst. Oceanogr., v. 42, n. 1/2, p. 35-54, 1994.

HARARI, J.; CAMARGO, R. Modelagem numérica da região costeira de Santos (SP): Circulação de maré. Rev. Bras. Oceanogr., v. 46, n. 2, p. 135-156, 1998.

HARARI, J.; CAMARGO, R. Numerical simulation of the tidal propagation in the coastal region of Santos (Brazil, $24^{\circ} \mathrm{S}$ $\left.46^{\circ} \mathrm{W}\right)$. Cont. Shelf Res., v. 23, n. 16, p.1597-1613, 2003.

LEENDERTSE, J. J. Aspects of a computational model for longperiod water-wave propagation. Santa Monica: Rand Corporation, 1967.

LEITÃO, P.; COELHO, H.; SANTOS, A.; NEVES, R. Modelling the main features of the Algarve coastal circulation during July 2004: a downscaling approach. J. Atmos. Ocean Sci., v. 10, n. 4, p. 421-462, 2005.

LONGUET-HIGGINS, M. S. The Eigen functions of Laplace's Tidal Equations over a Sphere. Philos. Trans. R. Soc London, v. 262, n. 1132, p. 511-607, 1968

MALHADAS, M. S.; LEITÃO, P. C.; SILVA, A.; NEVES, R. Effect of coastal waves on sea level in Óbidos Lagoon, Portugal. Cont. Shelf Res., v. 29, n. 9, p. 1240-1250, 2009.

MARTA-ALMEIDA, M.; PEREIRA, J.; CIRANO, M. Development of a pilot Brazilian regional operational ocean forecast system, REMO-OFF. J. Oper. Oceanogr., v. 4, p. 3-15, 2011.

MARTINS, F.; NEVES, R.; LEITAO, P. C. A three-dimensional hydrodynamic model with generic vertical coordinate. Hydroinformatics, v. 98, n. 2, p. 1403-1410, 1998.

MARTINS, F.; LEITÃO, P.; SILVA, A.; NEVES, R. 3D modelling in the Sado estuary using a new generic vertical discretisation approach. Oceanol. Acta, v. 24, p. 1-12, 2001. 
MATEUS, M.; RIFLET, G.; CHAMBEL, P.; FERNANDES, L.; FERNANDES, R.; JULIANO, M.; CAMPUZANO, F.; NEVES, R. An operational model for the West Iberian coast: products and services. Ocean Sci., v. 8, n. 1, p. 713-732, 2012.

MATSUMOTO, K.; TAKANEZAWA, T.; OOE, M. Ocean tide models developed by assimilating TOPS/POSEIDON altimeter data into hydrodynamical model: A global model and a regional model around Japan. J. Oceanogr., v. 56, p. 567-581, 2000.

MESQUITA, A. R.; HARARI, J. On the harmonic constants of tides and tidal currents of the South-eastern Brazilian shelf. Cont. Shelf Res., v. 23, n. 11/13, p. 1227-1237, 2003.

MONTERO, P.; GÓMEZ-GESTEIRA, M.; TABOADA, J. J.; RUIZ-VILLAREAL, M.; SANTOS, A. P.; PREGO, R.; PÉREZ-VILLAR, V. On residual circulation of the Ria of Vigo using a 3-D baroclinic model. Bol. Inst. Esp. Oceanogr., v. 15, n. 1/4, p. 31-38, 1999.

QUARESMA, L. S.; PICHON, A. Modelling the barotropic tide along West-Iberian margin. J. Mar. Syst., v. 109-110, p. 3-25, 2013.

RIFLET, G.; REFFRAY, G.; FERNANDES, R.; CHAMBEL, P.; NOGUEIRA, J.; NEVES, R. Downscaling a large-scale ocean-basin model: an intercomparison exercise in the bay of Biscay. In: PEREIRA, J. C. F.; SEQUEIRA, A. (Eds.). V European Conference on Computational Fluid Dynamics. Lisboa: Portugal, 2010. p. 14-17.

SALlES, F. J. P.; BENTES, F. C. M.; SANTOS, J. A. (Orgs.). Catálogo de Estações Maregráficas Brasileiras. Rio de Janeiro: Fundação de Estudos do Mar - FEMAR, 2000. 280 p.

SANTOS, A.; MARTINS, H.; COELHO, H.; LEITÃO, P.; NEVES, R. A. A circulation model for the European ocean margin. Appl. Math. Model., v. 26, n. 5, p. 563-582, 2002.
SARACENO, M.; D'ONOFRIO, E. E.; FIORE, M. E.; GRISMEYER, W. H. Tide model comparison over the Southwestern Atlantic Shelf. Cont. Shelf Res., v. 30, n. 17, p. 18651875, 2011.

SCHMID, C.; SCHÄFER, H.; PODESTÁ, G.; ZENK, W. The Vitória eddy and its relation to the Brazil Current. J. Phys. Oceanogr., v. 25, p. 2532-2546, 1995.

SILVEIRA, I. C. A.; SCHMIDT, A. C. K.; CAMPOS, E. J. D.; GODOI, S. S.; IKEDA, Y. A Corrente do Brasil ao largo da costa leste brasileira. Rev. Bras. Oceanogr., v. 48, n. 2, p. 171183,2000 .

STECH, J. L.; LORENZETTI, J. A. The response of the South Brazil Bight to the passage of wintertime cold fronts. J. Geophys. Res., v. 97, n. c6, p. 9507-9520, 1992.

VAZ, N.; DIAS, J. M.; LEITÃO, P. C. Three-dimensional modelling of a tidal channel: The Espinheito Channel (Portugal). Cont. Shelf. Res., v. 29, n. 1, p. 29-41, 2009.

VAZ, N.; DIAS, J. M.; LEITÃO, P. C.; MARTINS, I. Horizontal patterns of water temperature and salinity in an estuarine tidal channel: Ria de Aveiro. Ocean Dyn., v. 55, p. 416-429, 2005.

WILLMOTT, C. J.; ACKLESON, S. G.; DAVIS, R. E.; FEDDEMA, J. J.; KLINK, K. M.; LEGATES, D. R.; O'DONNELL, J.; ROWE, C. M. Statistics for the Evaluation and Comparison of Models. J. Geophys. Res., v. 90, n. c5, p. 8995-9005, 1985.

WILLMOTT, C. J.; MATSUURA, K. Advantages of the mean absolute error (MAE) over the root mean square error (RMSE) in assessing average model performance. Clim. Res., v. 30, n. 1, p. 79-82, 2005.

WILLMOTT, C. J.; ROBESON, S. M.; MATSUURA, K. Short communication: A refined index of model performance. Int. J. Climatol., v. 32, n. 13, p. 2088-2094, 2012. 